\title{
Regulation of the ovarian oxidative status by leptin during the ovulatory process in rats
}

\author{
María Guillermina Bilbao ${ }^{1}$, María Paula Di Yorio ${ }^{1}$, Rocío Alejandra Galarza , \\ Cecilia Laura Varone ${ }^{2}$ and Alicia Graciela Faletti ${ }^{1}$ \\ ${ }^{1}$ Centro de Estudios Farmacológicos y Botánicos (CEFYBO), Consejo Nacional de Investigaciones Científicas y \\ Técnicas (CONICET)-Facultad de Medicina Paraguay 2155, $16^{\circ}$ P, Buenos Aires, Argentina and ${ }^{2}$ Instituto de Química \\ Biológica de la Facultad de Ciencias Exactas y Naturales (IQUIBICEN), Consejo Nacional de Investigaciones \\ Científicas y Técnicas (CONICET)-Facultad de Ciencias Exactas y Naturales, Universidad de Buenos Aires, \\ Buenos Aires, Argentina \\ Correspondence should be addressed to A G Faletti; Email: alifaletti@gmail.com
}

\begin{abstract}
Leptin exerts both stimulatory and inhibitory effects on the ovulatory process. In this study, we investigated whether these opposite effects involve changes in the oxidative status in response to different levels of leptin. To this end, we performed both in vivo and in vitro assays using ovaries of immature rats primed with gonadotropins to induce ovulation. Superoxide dismutase (SOD) and catalase (CAT) activity, lipid peroxidation, glutathione (GSH) content, and reactive oxygen species (ROS) were studied as oxidative damage-related parameters. The expression of BCL2, BAX, and caspase 3 were measured by western blot as apoptosis-related biomarkers. The acute treatment with leptin, which inhibits ovulation, decreased SOD activity and increased active caspase 3 expression. No differences were found in CAT activity, lipid peroxidation, or total GSH. In contrast, the daily administration of leptin, which induces ovulation, decreased GSH content, ROS levels, and Bax and active caspase 3 expression, but caused no changes in other parameters. In addition, the daily administration of leptin induced follicular growth, measured by the number of antral follicles in ovarian sections. Using ovarian explant cultures, we found increased BCL2 expression and decreased SOD activity at low and high concentrations of leptin respectively. Thus, leptin can modulate the oxidative status of the ovarian tissue, during the ovulatory process, by acting on different targets according to its circulating levels. At low concentration, leptin seems to play a protective role against the oxidative stress, whereas at high concentrations, this protein seems to be involved in cell death. Reproduction (2015) 149 357-366
\end{abstract}

\section{Introduction}

Leptin, a circulating protein mainly synthesized by adipocytes, acts as an important regulatory hormone in multiple functions, including ovarian function (Zhang et al. 1994). Leptin acts through its receptors, which are widely distributed in many tissues, including the ovary (Karlsson et al. 1997, Zamorano et al. 1997, Agarwal et al. 1999, Duggal et al. 2002a). Both leptin and its receptors are expressed in granulosa, theca, interstitial, and cumulus cells of humans (Karlsson et al. 1997, Agarwal et al. 1999) and rats (Zachow et al. 1999, Archanco et al. 2003). Leptin is able to cause both stimulatory (Ahima et al. 1997, Almog et al. 2001, Barkan et al. 2005) and inhibitory (Duggal et al. 2000, 2002b, Lin et al. 2009) effects on the ovarian function. Similarly, some studies have demonstrated that leptin can exert a biphasic effect on the ovarian function (Ruiz-Cortés et al. 2003, Karamouti et al. 2008, 2009).

Ovulation is a complex process, considered as an inflammatory process (Richards et al. 2002), which is mediated by different molecules, including prostaglandins, proteolytic enzymes, cytokines, leukotrienes, nitric oxide, steroid hormones, and reactive oxygen species (ROS; Agarwal et al. 2012, Rizzo et al. 2012). Although oxidative stress may be a physiological state in certain conditions, it may increase when the production of ROS exceeds or saturates the antioxidant levels. ROS are of particular interest, as they have been shown to play a role in follicle rupture induced by gonadotropins (Agarwal et al. 2005, Shkolnik et al. 2011). Mitochondria and the metabolic processes are the main sources of ROS production in steroidogenic tissues (Fujii et al. 2005, Hanukoglu 2006), but excessive ROS can affect a tissue by producing excessive lipid peroxidation, oxidation, and different lesions in the DNA, which may, in turn, result in apoptosis (Valko et al. 2007). Tissues, including the ovary, have a delicate balance between ROS and antioxidant species. Ovarian cells have both enzymatic and nonenzymatic antioxidant defenses to counteract oxidant species (Agarwal et al. 2005, Angelucci et al. 2006). The ratio between the 
levels of oxidant and antioxidant defenses changes depending on the hormonal conditions. After the gonadotropin surge (human chorionic gonadotropin (hCG) or luteinizing hormone (LH)), ROS levels increase while the expression of antioxidants decrease to enhance ovulation (Laloraya et al. 1988, Sato et al. 1992, Shkolnik et al. 2011). Using in vivo and in vitro assays, it has been shown that antioxidants significantly reduce the LH-induced cumulus mucification/expansion, progesterone production, and activation of two signaling pathways (PKA and MAPK), all events indispensable for the ovulatory process (Shkolnik et al. 2011). Indeed, preovulatory follicles isolated from immature rats stimulated with gonadotropin to induce ovulation produce high levels of superoxide anion after $\mathrm{LH}$ administration (Kodaman \& Behrman 2001). ROS, such as superoxide anion radical and hydrogen peroxide, are considered essential to enhance steroidogenesis and ovulation (Sawada \& Carlson 1996, Shkolnik et al. 2011). Thus, and considering that i) LH-induced ROS production seems to be an essential preovulatory signaling event by being involved in the activation of different signaling pathways (MAPK and probably PKA) (Shkolnik et al. 2011); ii) leptin regulates the ovulatory process by modifying steroidogenesis (Bilbao et al. 2013); and iii) some evidences indicate that leptin decreases ROS levels (Balasubramaniyan et al. 2007) in parallel with an increase in the antioxidant defenses (Sailaja et al. 2004), we hypothesize that the leptin action may affect the oxidative status, such as ROS production or antioxidant defense bioavailability, depending on its circulating levels.

We have previously found that an acute treatment with leptin inhibits (Ricci et al. 2006), whereas a daily administration of low doses of leptin enhances (Roman et al. 2005) the ovulatory process in comparison with control animals. Moreover, we found that the dual action of leptin seems to occur by regulating steroidogenesis (Bilbao et al. 2013), which, in turn, is regulated, at least in part, by both ERK and STAT signaling pathways (Di Yorio et al. 2013). Thus, and considering the relationship between ovulation and ROS, we were interested in studying whether the dual and opposite effects of leptin on the ovulatory process involve changes in the balance of oxidative stress at ovarian level in response to this protein in rats.

\section{Materials and methods}

\section{Animals}

Immature female Sprague-Dawley rats aged 21 days were purchased from the School of Veterinarian Sciences of Buenos Aires University, Argentina. Animals were kept under controlled conditions of light (12 h light: $12 \mathrm{~h}$ darkness cycle), temperature $\left(22^{\circ} \mathrm{C}\right)$, and humidity, with free access to food and water. Animals were handled according to the Guiding
Principles for the Care and Use of Research Animals, and all the protocols were approved by the Institutional Committee of the School of Medicine of Buenos Aires University (CICUAL) by Resolution 2950/10.

\section{Experimental design}

\section{In vivo studies}

As shown in Fig. 1, prepubertal rats were i.p. injected with $15 \mathrm{IU}$ of equine chorionic gonadotropin (eCG) to induce the first generation of preovulatory follicles and to avoid the confounding effects of the presence of different types of follicles and corpora lutea from previous cycles. After $48 \mathrm{~h}$, the animals were i.p. injected with $15 \mathrm{IU}$ of hCG to induce ovulation.
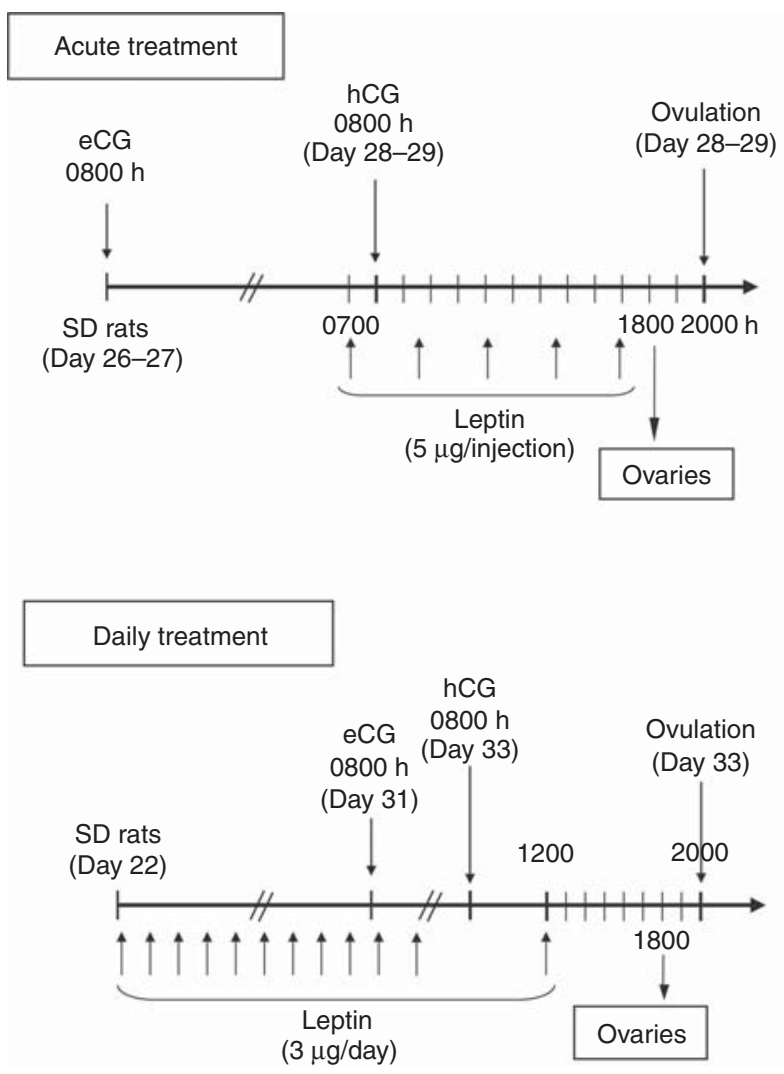

Figure 1 Schematic of the in vivo leptin treatments performed in our experiments. Acute treatment (upper panel): rats were injected with $15 \mathrm{IU}$ eCG at 26-27 days of age and $15 \mathrm{IU}$ hCG $48 \mathrm{~h}$ later. Both injections were administered at $0800 \mathrm{~h}$. Leptin ( $5 \mu \mathrm{g} /$ injection) was administered during the time period between $1 \mathrm{~h}$ before hCG administration and killing through five injections of recombinant rat leptin or vehicle at 150-min intervals $(0700,0930,1200,1430$, and $1700 \mathrm{~h}$; up arrow). Rats were killed by decapitation at $10 \mathrm{~h}(1800 \mathrm{~h})$ after hCG administration. Daily treatment (bottom panel): at 22 days of age, rats were daily injected with $3 \mu \mathrm{g}$ leptin or vehicle at $1200 \mathrm{~h}$ until killing. In total, the animals received 12 injections. In addition, all rats received $15 \mathrm{IU}$ eCG at 31 days of age and $15 \mathrm{IU}$ hCG $48 \mathrm{~h}$ later. Both injections were administered at $0800 \mathrm{~h}$. Rats were killed by decapitation at $10 \mathrm{~h}(1800 \mathrm{~h})$ after hCG administration. In this rat strain, ovulation occurs within $12 \mathrm{~h}$ after hCG administration. SD, Sprague-Dawley. 
In addition, these animals received one of the following treatments (Fig. 1): i) acute treatment (Ricci et al. 2006), which consisted of five i.p. injections of either recombinant rat leptin ( $5 \mu \mathrm{g} / 0.15 \mathrm{ml}$ of PBS-BSA) or PBS-BSA alone (control) $1 \mathrm{~h}$ before hCG administration and at 150-min intervals until killing and ii) daily treatment (Roman et al. 2005), at 22 days of age, which consisted of an i.p. injection of either recombinant rat leptin $(3 \mu \mathrm{g} / 0.15 \mathrm{ml}$ PBS-BSA) or PBS-BSA alone (control) per day until killing. After 10 days of this daily treatment, these animals were injected with gonadotropin as indicated before. In total, these animals received 12 injections of leptin.

Both treatments attempt to simulate rats exposed to: i) high levels of leptin (acute treatment), as it occurs in obese rats, which inhibit ovulation (Duggal et al. 2000, Ricci et al. 2006) and ii) leptin levels that induce ovulation (daily treatment; Almog et al. 2001, Roman et al. 2005). All the rats were killed by decapitation $10 \mathrm{~h}$ after hCG administration and both ovaries were immediately dissected out, homogenized as indicated below or frozen on dry ice, and stored at $-78{ }^{\circ} \mathrm{C}$ until use. We used only ovaries with an adequate size and weight that represent gonadotropin-induced stimulation (Espey et al. 2000).

\section{In vitro studies}

Animals were killed by decapitation $4 \mathrm{~h}$ after $\mathrm{hCG}$ administration and the ovarian tissue was incubated as described previously (Ricci et al. 2006). Briefly, ovarian slices (four slices per ovary per well) were randomly distributed in 24-well plates containing $500 \mu \mathrm{l} /$ well of DMEM/F12 (1:1) medium (Bio-Rad Laboratories) with $25 \mathrm{mmol} / \mathrm{l} \mathrm{HEPES}, 100 \mu \mathrm{g} / \mathrm{ml}$ streptomycin, $0.5 \mu \mathrm{g} / \mathrm{ml}$ fungizone, and $2 \mathrm{mmol} / \mathrm{l}$ L-glutamine, and different leptin concentrations $(0.3-300 \mathrm{ng} / \mathrm{ml}$ ) (Duggal et al. 2000, 2002b, Ricci et al. 2006) at $37^{\circ} \mathrm{C}$ in a humidified atmosphere $\left(5 \% \mathrm{CO}_{2}: 95 \% \mathrm{O}_{2}\right)$. After $4 \mathrm{~h}$ of incubation, ovarian tissues were recovered, homogenized as indicated below or frozen on dry ice, and stored at $-78{ }^{\circ} \mathrm{C}$ until use. Each experiment was repeated at least six times.

\section{Quantification of the activity of antioxidant enzymes: superoxide dismutase and catalase}

Each ovary, immediately dissected out after killing the rats, was homogenized in $20 \mathrm{mmol} / \mathrm{l}$ ice-cold Tris- $\mathrm{HCl}$ buffer $(\mathrm{pH} 7.6)$ containing $1 \mathrm{mmol} / \mathrm{I}$ EDTA, $150 \mathrm{mmol} / \mathrm{l} \mathrm{KCl}, 1 \mathrm{mmol} / \mathrm{l}$ 2-mercaptoethanol, and $500 \mathrm{mmol} / / \mathrm{l}$ sucrose, and centrifuged at $800 \mathrm{~g}$ for $10 \mathrm{~min}$ at $4{ }^{\circ} \mathrm{C}$. Supernatants were used for superoxide dismutase (SOD) and catalase (CAT) assays and to measure the protein concentration by the Bradford method with BSA as the standard.

SOD activity was assessed as described previously (Misra \& Fridovich 1972). This assay is based on the ability of SOD to inhibit the autoxidation of superoxide-induced epinephrine to adrenochrome, which is quantified by a spectrophotometer at an absorbance of $480 \mathrm{~nm}$. The reaction mixture contained $30 \mathrm{mmol} / \mathrm{l}$ epinephrine in $0.05 \%(\mathrm{v} / \mathrm{v})$ acetic acid, $50 \mathrm{mmol} / \mathrm{l}$ glycine buffer ( $\mathrm{pH} 10.2$ ), and different volumes of supernatants. The change in SOD activity was measured for 4 min at 10-s intervals. Results are expressed as units of SOD per milligram of protein.
CAT activity was assayed as described previously (Aebi 1984), based on the ability of CAT to catalyze the conversion of hydrogen peroxide $\left(\mathrm{H}_{2} \mathrm{O}_{2}\right)$ to molecular oxygen and water. To this end, supernatants were incubated with $1 \mathrm{mmol} / / \mathrm{H}_{2} \mathrm{O}_{2}$ in $50 \mathrm{mmol} / \mathrm{l} \mathrm{PBS}, \mathrm{pH}$ 7.2. The rate of decrease in $\mathrm{H}_{2} \mathrm{O}_{2}$ absorbance was measured for 1 min at 10-s intervals by a spectrophotometer at an absorbance of $240 \mathrm{~nm}$. Results are expressed as micromoles of CAT per milligram of protein.

\section{Oxidative damage-related parameters}

Each ovary, immediately dissected out after killing the rats, was homogenized in $0.5 \%(\mathrm{w} / \mathrm{v})$ trichloroacetic acid at $4{ }^{\circ} \mathrm{C}$ and centrifuged at $10000 \mathrm{~g}$ for $10 \mathrm{~min}$ at $4^{\circ} \mathrm{C}$. Supernatants were used to measure the presence of both malondialdehyde (MDA, as an index of lipid peroxidation) and total glutathione (GSH, as an indicator of antioxidant defense consumption). Protein concentration in these supernatants was determined by the Bradford method, with BSA as the standard.

\section{Lipid peroxidation}

As an index of lipid peroxidation, we used the formation of thiobarbituric acid-reactive species (TBARS) by measuring the amount of MDA, formed from the breakdown of polyunsaturated fatty acids during an acid heating reaction, as described previously (Ohkawa et al. 1979). Briefly, the supernatants were mixed with $0.67 \%(\mathrm{w} / \mathrm{v})$ thiobarbituric acid (Merck) and heated in a boiling water bath for $20 \mathrm{~min}$. After cooling, the absorbance of each sample was determined at $535 \mathrm{~nm}$ using a Beckman Coulter u.v./Visible (DU800). TBARS content was expressed in micromoles of MDA formed per milligram of protein.

\section{Total GSH content}

GSH content was determined by an enzymatic assay as described previously (Tietze 1969). Briefly, the supernatants were incubated with $0.24 \mathrm{mmol} / \mathrm{I} \mathrm{NADPH}, 0.75 \mathrm{mmol} / \mathrm{I}$ 5,5'-dithiobis-2-nitrobenzoic acid in PBS $0.05 \mathrm{M}, \mathrm{pH} 7.4$, and $2.5 \mathrm{IU}$ GSH reductase, and the development of the chromophoric product was recorded every $30 \mathrm{~s}$ for $6 \mathrm{~min}$ at an absorbance of $412 \mathrm{~nm}$ using a Beckman Coulter u.v./Visible (DU800). Total GSH content was expressed in micromoles GSH per milligram of protein.

\section{In situ ROS detection}

Whole ovaries, immediately dissected out after killing the rats, were used to determine the presence of ROS, as described previously (Tsai-Turton \& Luderer 2006). Each ovary was incubated with $100 \mu \mathrm{mol} / \mathrm{l} 2^{\prime}, 7^{\prime}$-dichlorofluorescein diacetate $\left(\mathrm{H}_{2}\right.$ DCFDA) (Sigma-Aldrich) in DMEM/F12 (1:1) containing $0.5 \mu \mathrm{g} / \mathrm{ml}$ fungizone and $2 \mu \mathrm{g} / \mathrm{ml}$ gentamicin at $37^{\circ} \mathrm{C}$ in a humidified atmosphere $\left(5 \% \mathrm{CO}_{2}: 95 \% \mathrm{O}_{2}\right)$ for $30 \mathrm{~min}$. After incubation, ovaries were washed with PBS, fixed in buffered formalin, fixed in $70 \%$ ethanol, dehydrated, and finally included in paraffin. Then, the tissues were serially sectioned at $5 \mu \mathrm{m}$ thickness and mounted onto glass slides, and fluorescence intensity was measured every 20 sections. $\mathrm{H}_{2}$ DCFDA diffuses easily into the cells, where it is converted by cytosolic esterases 
to the nonfluorescent compound dichlorofluorescein $\left(\mathrm{H}_{2} \mathrm{DCF}\right)$, which is, in turn, oxidized to the fluorescent dichlorofluorescein (DCF) in the presence of ROS. As DCF fluorescence is considered a direct indicator of the presence of ROS, the fluorescence intensity was quantified under a Zeiss LSM 511 META laser scanning confocal microscope using a PlanNeofluor 10/0.3 objective with Cy2/alexa/fluorescein isothiocyanate excitation and a BP-500-530 filter for emission. Four sections from the same ovary and four to five ovaries from different animals with the same treatment were analyzed in each group and the ratio between the fluorescent area and the total area was used for statistical analyses using the freely available Image Pro Plus and ImageJ Software.

\section{Protein isolation by western blot}

Soluble tissue extracts, obtained from one ovary of each rat, were prepared as described previously (Bilbao et al. 2013). Briefly, proteins were isolated from the organic phase of the frozen tissues using TRI Reagent (Molecular Research Center) according to the manufacturer's instructions. Equal amounts of protein $(100 \mu \mathrm{g})$ were separated by SDS-PAGE $(12 \%)$. Proteins were transferred onto PVDF membranes (Bio-Rad Laboratories) for $60 \mathrm{~min}$ in a cold chamber using a Bio-Rad transblot apparatus. Membranes were first blocked at $4{ }^{\circ} \mathrm{C}$ overnight in Tris-HCl:saline (50 mmol// Tris- $\mathrm{HCl}: 150 \mathrm{mmol} / \mathrm{l} \mathrm{NaCl}, \mathrm{pH} 7.5$ ) containing $5 \%(\mathrm{w} / \mathrm{v})$ of non-fat milk powder, and then incubated at $4{ }^{\circ} \mathrm{C}$ for $48 \mathrm{~h}$ with specific antibodies. Rabbit anti-caspase $3(\mathrm{H}-277)$, anti-Bax $(\mathrm{N}-20)$, and anti-Bcl-2 $(\mathrm{N}-19)$ polyclonal antibodies (Santa Cruz Biotechnology), and rabbit anti-actin polyclonal antibody (A2066, Sigma-Aldrich) each diluted 1/200 were used. After washing, membranes were treated for $1 \mathrm{~h}$ at room temperature with a goat anti-rabbit IgG (diluted 1/2500) as the secondary antibody (Santa Cruz Biotechnology). Immunoreactive bands were visualized using chemiluminescence detection reagents (Sigma-Aldrich) and Image Quant RT ECL (General Electric, Amersham Bioscience Argentina SA), and quantified using the ImageJ Software. Before reuse, membranes were stripped, blocked, and reprobed according to the manufacturer's instructions. Negative controls were carried out by omitting the incubation with the primary antibody and no bands were detected. Molecular weight standards (Kaleidoscope, Bio-Rad Laboratories) were run under the same conditions to identify the protein bands. The data were normalized to $\beta$-actin protein levels in each sample to avoid procedural variability.

\section{Ovarian histology and follicle counting}

To assess the effect of the daily treatment with leptin on follicular growth, antral follicles were counted in histological sections prepared from ovaries as described previously (Barreiro et al. 2011). Briefly, each ovary was fixed in formalin, dehydrated and serially sectioned at $5 \mu \mathrm{m}$ thickness and stained with hematoxylin and eosin according to standard protocols and analyzed using an Olympus CX21 microscope. Ovarian antral follicles were analyzed every ten sections and only follicles containing an oocyte were counted to avoid double counting the follicles. Ten sections from the same ovary and five or six ovaries from different animals with the same treatment were analyzed in each group. Follicle abundance was normalized by the total ovarian area in the section, as reported previously (Cheng et al. 2002, Barreiro et al. 2011). Ovarian area was measured using Image J (version 1.42q) and expressed per $10 \mathrm{~mm}^{2}$.

\section{Statistical analysis}

All data are expressed as means \pm s.E.M. Differences between two groups were analyzed using Student's $t$-test. Comparisons between more than two groups were performed using one-way ANOVA and Dunnett's multiple comparison test. Levene's test and a modified Shapiro-Wilk test were used to assess homogeneity of variances and normal distribution respectively. If these assumptions were not met, a logarithmic transformation was applied to the data before ANOVA. If the transformation did not result in homogeneous variances, two nonparametric tests, the Mann-Whitney $U$ and Kruskal-Wallis tests, were used to assess the differences between two groups and more than two groups respectively. Differences between groups were considered significant when $P<0.05$.

\section{Results \\ In vivo studies}

Table 1 shows the results obtained regarding SOD and CAT activities and MDA and total GSH contents in the

Table 1 Effect of both the acute and the daily treatments with leptin on the activity of two antioxidant enzymes, superoxide dismutase (SOD), and catalase (CAT), and two oxidative damage-related parameters, the concentration of malondialdehyde (MDA), as an indicator of lipid peroxidation, and the concentration of total glutathione $(\mathrm{GSH})$ in rat ovaries. Values are expressed as means \pm s.E.M. $(n=6-8)$ and were obtained by separate experiments.

\begin{tabular}{|c|c|c|c|c|}
\hline & \multicolumn{2}{|c|}{ Acute treatment } & \multicolumn{2}{|c|}{ Daily treatment } \\
\hline & Control & Leptin & Control & Leptin \\
\hline SOD (IU/mg protein) & $148 \pm 13$ & $111 \pm 8^{*}$ & $65 \pm 9$ & $66 \pm 7$ \\
\hline CAT ( $\mu \mathrm{mol} / \mathrm{mg}$ protein) & $85 \pm 22$ & $93 \pm 17$ & $222 \pm 31$ & $153 \pm 24$ \\
\hline $\mathrm{GSH}(\mu \mathrm{mol} / \mathrm{mg}$ protein) & $21 \pm 2$ & $23 \pm 2$ & $45 \pm 9$ & $25 \pm 2^{+}$ \\
\hline MDA ( $\mu \mathrm{mol} / \mathrm{mg}$ protein $)$ & $131 \pm 12$ & $140 \pm 9$ & $106 \pm 16$ & $106 \pm 5$ \\
\hline
\end{tabular}

Acute treatment: ${ }^{*} P<0.05$ vs control. Student's $t$-test was used for SOD, CAT, and GSH, and a nonparametric test, the Mann-Whitney $U$ test, was used for MDA. Daily treatment: ${ }^{\dagger} P<0.05$ vs the respective control. Student's $t$-test was used for SOD and CAT, and a nonparametric test, the Mann-Whitney $U$ test, was used for GSH and MDA. 

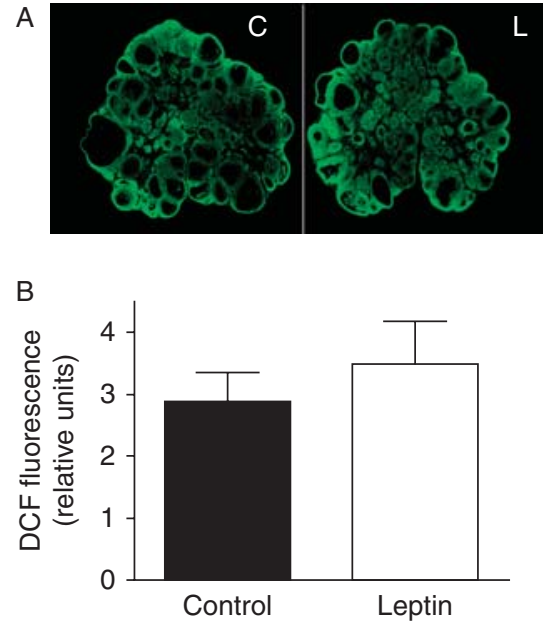

Figure 2 In vivo effect of the acute treatment with leptin on reactive oxygen species (ROS) levels in the ovarian tissue by dichlorofluorescein (DCF) fluorescence. Immature rats were primed with eCG/hCG and treated either with vehicle (control) or with $5 \mu \mathrm{g}$ leptin $1 \mathrm{~h}$ before hCG administration and at 150-min intervals. Animals were killed $10 \mathrm{~h}$ after hCG administration. ROS production was assessed by measuring DCF fluorescence by laser scanning confocal microscopy as detailed in the Materials and methods section. (A) Representative images show DCF fluorescence in both the control (C) and leptin-treated tissue (L). (B) Mean \pm S.E.M. of DCF fluorescence intensity expressed as relative units ( $n=4-5$ ovaries/group).

ovarian tissue from rats that had received both the acute and daily treatments with leptin. After the acute treatment, SOD activity was significantly lower $(25 \%$, $P<0.05)$ than that of control animals, without changes in the other parameters evaluated. However, after the daily treatment, the ovaries had a significant decrease in total GSH content $(44 \%, P<0.05)$ compared with controls, without differences in the other parameters.

When we studied the presence of ROS in the ovarian tissue, we found no differences between rats acutely treated with leptin and controls, as the fluorescence intensity of DCF was similar in both groups (Fig. 2). In contrast, the ovaries from animals treated daily with leptin exhibited an abrupt decrease in the fluorescence $(67 \%, P<0.001)$ compared with controls (Fig. 3$)$.

By western blot, all the ovarian tissues obtained from the in vivo experiments revealed the presence of BCL2 (26 kDa), BAX (23 kDa), procaspase 3 (42 kDa), and caspase 3 p17 $(17 \mathrm{kDa})$, the latter of which represents active caspase 3 . The acute treatment with leptin did not alter the ovarian expression of $\mathrm{BCl} 2$ or $\mathrm{BAX}$ (Fig. 4A) when compared with controls. However, this treatment was able to increase the expression of caspase 3 p17 $(56 \%, P<0.01)$ but not that of procaspase 3 (Fig. 4B). The daily treatment with leptin decreased the expressions of both $\mathrm{BAX}(20 \%, P<0.05)$ (Fig. 5A) and caspase 3 p17 (38\%, $P<0.01)$ (Fig. 5B) compared with controls but not those of $\mathrm{Bcl} 2$ or procaspase 3 (Fig. 5).
To complete previous studies where a daily stimulus with low doses of leptin accelerated the follicular maturation (Almog et al. 2001) and increased both steroidogenesis (Roman et al. 2005) and the ovulation rate (Almog et al. 2001, Roman et al. 2005), antral follicles were counted to study whether this treatment was able to increase follicular growth. Figure 6 shows the results of the histological evaluation of the ovarian sections. The number of antral follicles was 5.6-fold higher in the leptin-treated animals than in control animals $(P<0.01)$.

\section{In vitro studies}

To study the direct effect of a narrow range of leptin concentrations, some parameters studied in the in vivo experiments were measured in ovarian explant cultures after $4 \mathrm{~h}$ of incubation (results are shown in Table 2). Leptin showed no effects on CAT activity, GSH content, or MDA levels. However, the ovarian tissue exposed to high concentrations of leptin clearly exhibited lower activity of SOD than the control tissues, although this reduction was only significant at $100 \mathrm{ng} / \mathrm{ml}(P<0.05$; Table 2). Unlike that observed in the in vivo experiments, we were not able to detect the bands corresponding to caspase 3 p17 and the presence of leptin did not alter the expression of procaspase 3 (data not shown). Nevertheless, BCL2 expression increased at $1 \mathrm{ng} / \mathrm{ml}$ $(201 \%, P<0.01)$ of leptin when compared with controls, whereas Bax expression showed no changes (Fig. 7).
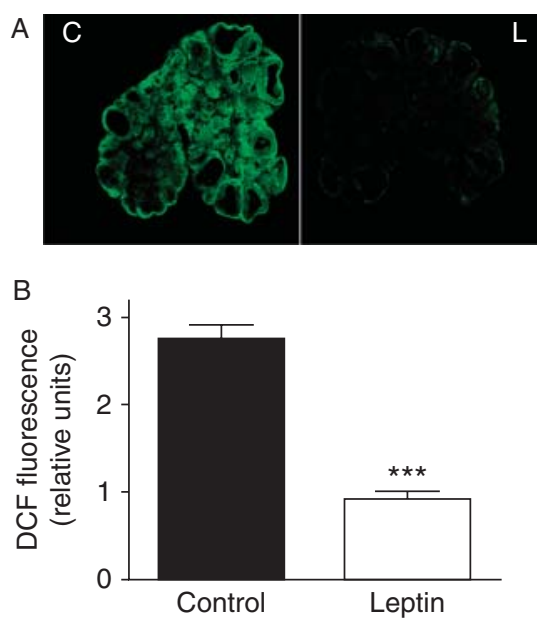

Figure 3 In vivo effect of the daily treatment with leptin on reactive oxygen species (ROS) levels in the ovarian tissue by DCF fluorescence. On day 22 of age, rats received injections of either vehicle (control) or $3 \mu \mathrm{g}$ leptin/day. After 10 days of treatment, animals received eCG/hCG stimulation as indicated in the Materials and methods section. Animals were killed $10 \mathrm{~h}$ after hCG administration. (A) Representative images show DCF fluorescence in both the control (C) and leptin-treated tissue (L). (B) Mean \pm S.E.M. of DCF fluorescence intensity expressed as relative units ( $n=4-5$ ovaries/group). ${ }^{* * *} P<0.001$ vs controls (Student's $t$-test). 


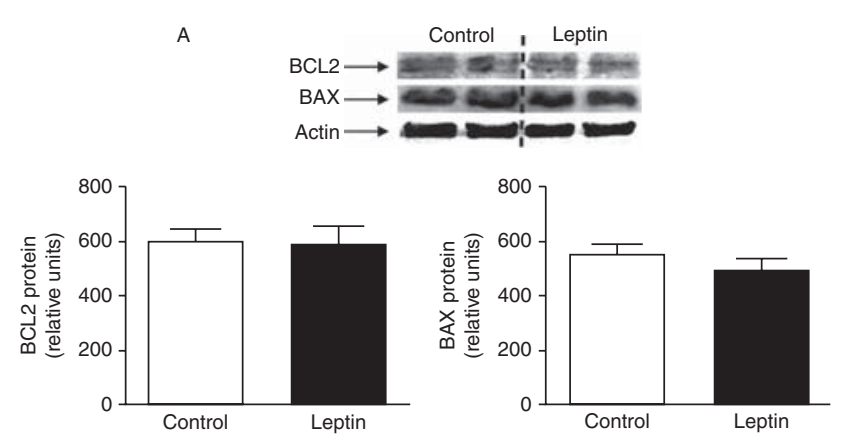

B
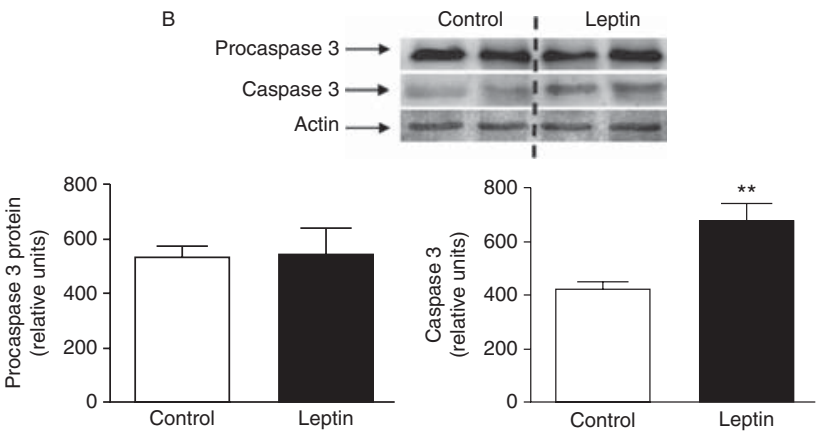

Figure 4 In vivo effect of the acute treatment with leptin on the ovarian expression of BCL2, BAX (A), procaspase 3, and caspase 3 (B). Immature rats were primed with eCG/hCG and treated either with vehicle (control) or with $5 \mu \mathrm{g}$ leptin $1 \mathrm{~h}$ before hCG administration and at 150-min intervals. Animals were killed $10 \mathrm{~h}$ after hCG administration. ( $A$ and $B$ ) Representative blots (upper panel) showing protein expression of BCL2, BAX (A), procaspase 3 , caspase $3(B)$, and $\beta$-actin (as protein control) by western blot, and quantitative analysis (bottom panel) of immunoreactive bands. Results are expressed as the mean \pm S.E.M. for six to eight samples per group. Each sample represents one ovary from each animal with the same treatment $(n=6-8)$. ${ }^{* *} P<0.01$ vs control (Student's $t$-test).

\section{Discussion}

In the present work, we studied whether the dual action of leptin in the ovulatory process involves changes in the oxidative status by evaluating some antioxidant defenses, ROS levels, and some oxidative damage-related parameters. SOD is the first enzymatic defense against ROS generated by the tissue as this enzyme catalyzes the reaction of superoxide anion radicals and dismutation to hydrogen peroxide, which is then converted into water by other enzymes, such as CAT or GSH peroxidase (GPx; Fridovich 1995, Hanukoglu 2006). As the acute administration of leptin caused a decrease in SOD activity, it is expected that this inhibitory effect results in a decrease in the levels of hydrogen peroxide. While it is difficult to compare an in vivo effect caused by a tissue directly exposed to effective and known doses, this result is consistent with that obtained in our in vitro studies as the presence of a high concentration of leptin inhibited ovarian SOD activity. These results also support those obtained in other in vitro studies, where leptin caused an increase in ROS levels (Yamagishi et al. 2001, Xu et al. 2004, Chetboun et al. 2012). Steroidogenesis is an important source of free radical production as the enzymes involved in the different steps in the biosynthesis of steroids (cytochrome P450 family and others) transfer electrons to different molecules producing ROS (Rapoport et al. 1995, Hanukoglu 2006). SOD expression in developing follicles correlates positively with steroidogenesis (Suzuki et al. 1999) and seems to play a role generating hydrogen peroxide, which drives the peroxidase-ascorbate system, responsible for production of progesterone (Agrawal \& Laloraya 1977, Laloraya et al. 1988, Suzuki et al. 1999). Therefore, a decrease in SOD activity, caused by the acute treatment with leptin, which implies lower production of hydrogen peroxide, could be altering the peroxidase-ascorbate system involved in the conversion of pregnenolone to progesterone. This hypothesis is consistent with the results obtained from previous studies where we found that the acute treatment with leptin inhibited the plasma progesterone levels (Ricci et al. 2006) and the expression of cytochrome P450 side chain cleavage (Bilbao et al. 2013), an enzyme involved in the conversion of pregnenolone to progesterone.

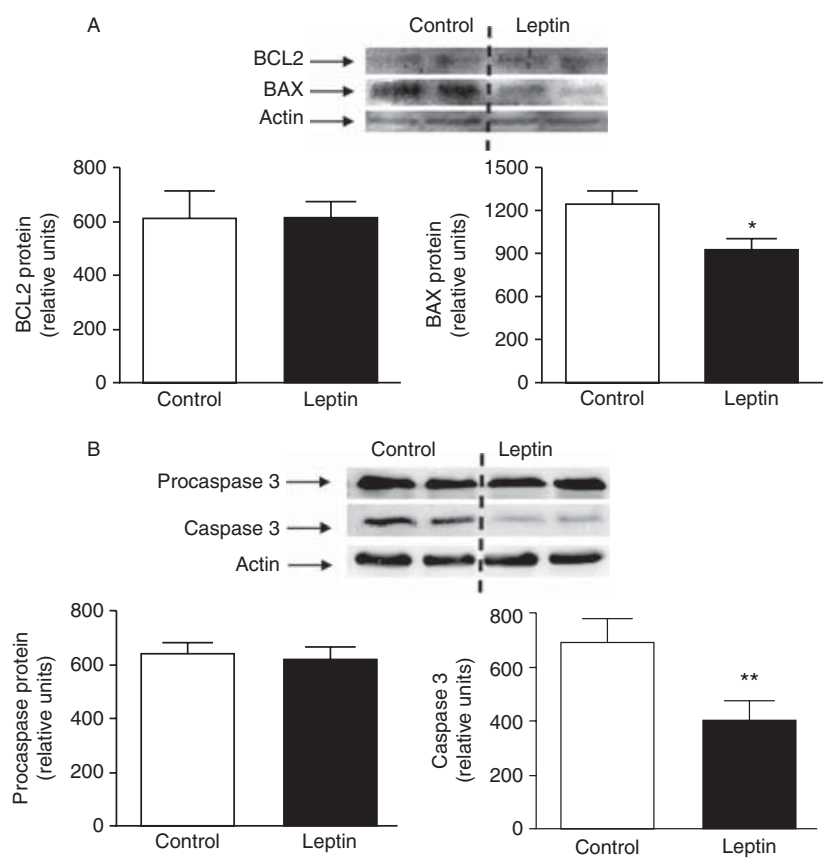

Figure 5 In vivo effect of the daily treatment with leptin on the ovarian expression of BCL2, BAX (A), procaspase 3, and caspase 3 (B). On day 22 of age, rats received injections of either vehicle (control) or $3 \mu \mathrm{g}$ leptin/day. After 10 days of treatment, animals received eCG/hCG stimulation as indicated in the Materials and methods section. Animals were killed $10 \mathrm{~h}$ after hCG administration. (A and B) Representative blots (upper panel) showing protein expression of BCL2, BAX (A), procaspase 3 , caspase $3(\mathrm{~B})$, and $\beta$-actin (as protein control) by western blot, and quantitative analysis (bottom panel) of immunoreactive bands. Results are expressed as the mean \pm s.E.M. for six to eight samples per group. Each sample represents one ovary from each animal with the same treatment $(n=6-8) .{ }^{*} P<0.05$ and ${ }^{* *} P<0.01$ vs control (Student's $t$-test). 

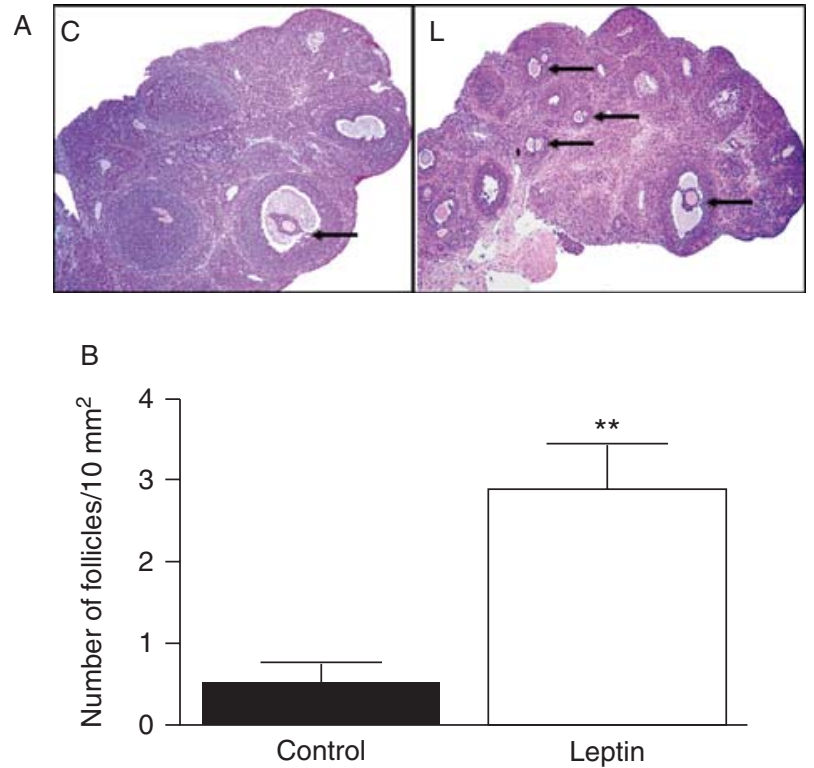

Figure 6 In vivo effect of the daily treatment with leptin on follicular growth by measuring the number of antral follicles in histological sections. On day 22 of age, rats received injections of either vehicle (control) or $3 \mu \mathrm{g}$ leptin/day. After 10 days of treatment, animals received eCG/hCG stimulation as indicated in the Materials and methods section. Animals were killed $10 \mathrm{~h}$ after hCG administration. (A) Histological appearance of ovarian sections from animals treated with vehicle (C) or leptin (L) stained with hematoxylin and eosin. (B) Values are expressed as the number of follicles per $10 \mathrm{~mm}^{2}$.

Data represent the mean \pm S.E.M. for six ovaries from different animals with the same treatment, and whose values represent the mean of ten sections from the same ovary. Arrow: antral follicles. ${ }^{* *} P<0.01$ vs vehicle (Control) (Student's $t$-test). Magnification: $\times 100$.

Unlike that observed in rats treated with the acute treatment, rats treated daily with leptin exhibited lower levels of total GSH in the ovarian tissue when compared with control animals. GSH regulates the cellular redox status as a scavenger of different free radicals such as hydroxyl radicals, superoxide anions, and peroxynitrite, or by acting as a substrate for both GPx and GSH S-transferase enzymes to detoxify hydrogen peroxide and lipid peroxides (Griffith 1999, Espey \& Richards 2002, Devine et al. 2012). These reactions induce the formation of GSH disulfide (GSSG), its oxidized form, which, in turn, is reduced to GSH by GSH reductase. Thus, under physiological conditions, the concentration of GSH is higher than that of GSSG to protect the cell from further oxidative damage. In addition, GSH is synthesized by two sequential enzymatic reactions that are catalyzed by glutamate cysteine ligase $(\mathrm{GCL})$ and GSH synthase, whose activities are induced by oxidative stress (Lu 2009). Tsai-Turton \& Luderer (2005) demonstrated that gonadotropins regulate ovarian synthesis of $\mathrm{GSH}$ by regulating the expression of the rate-limiting enzyme, GCL, in a follicle stage-dependent manner. All these data suggest that daily stimulation with low doses of leptin causes a lower generation of GSH probably by regulating the activity of GCL and/or GSH synthase. On the other hand, and although no changes were found in SOD and CAT activities or MDA concentrations, the ovarian tissue from animals treated daily with leptin exhibited an important decrease in the fluorescence intensity of DCF, which indicates an important decrease in ROS levels. It has been reported that cytochrome $c$ is a potent catalyst of $\mathrm{H}_{2}$ DCF oxidation and that the increased DCF production can be attributed to an increased cytosolic concentration of the cytochrome rather than an actual change in the ROS status (Kooy et al. 1997, Lawrence et al. 2003). In addition, Lawrence et al. (2003) showed that the rate of $\mathrm{H}_{2}$ DCF oxidation is highly sensitive to GSH concentrations, and that GSH and $\mathrm{H}_{2}$ DCF compete for oxidation by the same oxidizing species. The mechanism by which a daily leptin stimulus downregulates GSH content or ROS levels remains yet to be determined. However, and considering all these data and our results, it is reasonable to suggest that: i) GSH formation is not induced in the absence of oxidative stress and ii) the low concentrations of GSH caused by the daily treatment with leptin may be the result of its oxidation by other oxidant agents or by regulation on the activity of the enzymes involved in its synthesis.

Cell death by apoptosis is the mechanism involved in both follicular atresia and luteolysis. Activation of caspase 3 and increased expression of Bax, among others, are biomarkers of cell apoptosis. Both proteins are

Table 2 In vitro effect of different concentrations of leptin on the activity of two antioxidant enzymes, the superoxide dismutase (SOD) and catalase (CAT), and two oxidative damage-related parameters, the concentration of malondialdehyde (MDA), as an indicator of lipid peroxidation, and the concentration of total glutathione (GSH) by cultures of ovarian explants, from immature gonadotropin-primed rats. Values are expressed as means \pm S.E.M. $(n=8)$.

\begin{tabular}{|c|c|c|c|c|c|c|c|c|}
\hline & \multirow{2}{*}{ Ctrl } & \multicolumn{7}{|c|}{ Leptin (ng/ml) } \\
\hline & & 0.3 & 1 & 3 & 10 & 30 & 100 & 300 \\
\hline SOD (IU/mg protein) & $21 \pm 3$ & $21 \pm 2$ & $21 \pm 2$ & $15 \pm 2$ & $15 \pm 2$ & $15 \pm 1$ & $11 \pm 4^{*}$ & $12 \pm 2$ \\
\hline CAT ( $\mu \mathrm{mol} / \mathrm{mg}$ protein) & $274 \pm 23$ & $307 \pm 26$ & $268 \pm 29$ & $273 \pm 39$ & $265 \pm 14$ & $288 \pm 35$ & $239 \pm 10$ & $259 \pm 44$ \\
\hline $\mathrm{GSH}(\mu \mathrm{mol} / \mathrm{mg}$ protein) & $81 \pm 18$ & $79 \pm 8$ & $82 \pm 9$ & $85 \pm 11$ & $115 \pm 19$ & $86 \pm 6$ & $122 \pm 23$ & $92 \pm 18$ \\
\hline $\mathrm{MDA}(\mu \mathrm{mol} / \mathrm{mg}$ protein) & $121 \pm 11$ & $114 \pm 2$ & $108 \pm 2$ & $106 \pm 3$ & $109 \pm 4$ & $131 \pm 15$ & $123 \pm 8$ & $122 \pm 12$ \\
\hline
\end{tabular}

$* P<0.05$ vs control (Ctrl). One-way ANOVA and Dunnett's multiple comparison test were used for SOD and CAT, and a nonparametric test, the Kruskal-Wallis test, was used for GSH and MDA. 


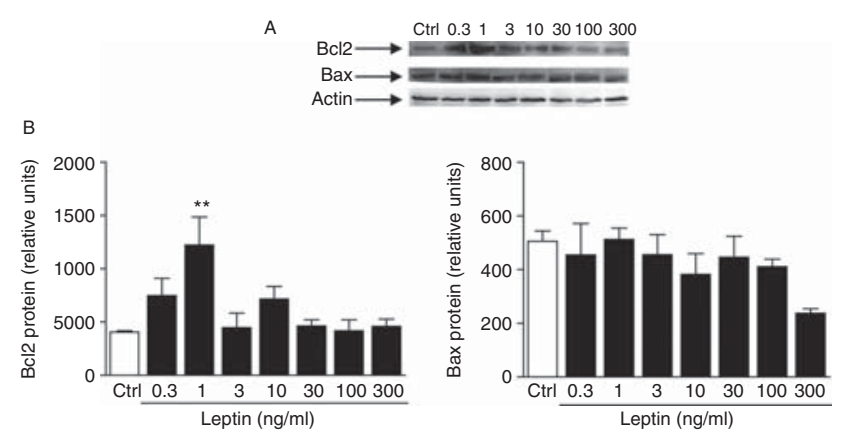

Figure 7 In vitro effect of leptin on the ovarian expression of $\mathrm{Bcl} 2$ and Bax. Ovarian explants were obtained $4 \mathrm{~h}$ after $\mathrm{hCG}$ administration from immature rats primed with eCG/hCG and incubated for $4 \mathrm{~h}$ either in the presence or in the absence (control) of different concentrations of leptin $(0.3-300 \mathrm{ng} / \mathrm{ml})$. (A) Representative blots showing the protein expression of $\mathrm{Bcl} 2, \mathrm{Bax}$, and $\beta$-actin (as protein control) by western blot. (B) Quantitative analysis of immunoreactive bands. Results are expressed as the mean \pm S.E.M. for five to six samples per group. Each sample represents one ovary from each animal with the same treatment. ${ }^{* *} P<0.01$ vs control (Ctrl) (one-way ANOVA and Dunnett's multiple comparison test).

mainly expressed in atretic follicles while anti-apoptotic $\mathrm{BCL} 2$ is abundant in healthy preantral follicles (Slot et al. 2006). Caspase 3 activation is an irreversible event during cell apoptosis. The fact that the acute treatment with leptin increased the expression of active caspase 3 but showed no changes in BAX and BCL2 or in ROS levels may indicate an involvement of the death receptor pathway rather than the mitochondrial pathway in caspase 3 activation. However, further studies are necessary to investigate the mechanism by which leptin activates caspase 3 .

Unlike the acute treatment, the daily administration of leptin decreased the ovarian expression of both Bax and active caspase 3, which is consistent with the fact that: i) these animals exhibited a higher follicular development and ii) the ovarian tissue directly exposed to physiological concentrations of leptin caused an increase in BCL2 expression. These results are supported by previous studies that demonstrated that similar daily administrations with leptin reduce the incidence of follicular apoptosis after 7 days of leptin injection and that leptin may be involved in accelerating follicular maturation by attenuating follicular atresia through an increase in the BCL2/BAX ratio (Almog et al. 2001). In addition, using different in vitro systems, other authors have found that leptin reduces apoptosis and induces cell proliferation, at least in part, by upregulating BCL2 expression (Brown \& Dunmore 2007, Sirotkin \& Grossmann 2007, Lam et al. 2010), and that leptin may act as an anti-apoptotic factor in luteinized porcine granulosa cells by increasing BCL2 expression and decreasing caspase 3 activity (Dineva et al. 2007). It is noteworthy that neither the acute nor the daily treatment altered procaspase 3 expression. This result indicates that leptin acts specifically on the cleavage process of the protein and consequently regulates the active protein without significantly altering procaspase 3 expression.

In conclusion, leptin can modulate the oxidative status according to its circulating levels. The fact that a daily stimulus with low doses of leptin, which induces follicular growth, decreases ROS levels and BAX and active caspase 3 expression indicates that leptin seems to exert a protective role in the ovarian tissue, as an antioxidant molecule, by attenuating follicular atresia. In contrast, at high concentrations, leptin may be involved in the loss of cell viability by activating caspase 3 through the death receptor pathway rather than through the mitochondrial pathway. All these data suggest that leptin seems to have a mediating role in reproduction by acting on different targets, at both intraand extra-ovarian levels, as it can either upregulate or downregulate the ovarian function according to its circulating concentration. Thus, specific leptin levels are necessary to ensure a normal ovarian function.

\section{Declaration of interest}

The authors declare that there is no conflict of interest that could be perceived as prejudicing the impartiality of the research reported.

\section{Funding}

This work was supported by grant PIP 112-20080-00271 from Consejo Nacional de Investigaciones Científicas y Técnicas (CONICET) and UBACYT 20020100100280 from Universidad de Buenos Aires, Argentina.

\section{Acknowledgements}

The authors thank Marcela Marquez and Enzo Cuba for their technical assistances in the maintenance and treatments of animals.

\section{References}

Aebi H 1984 Catalase in vitro. Methods in Enzymology 105 121-126. Agrawal P \& Laloraya MM 1977 Induction of peroxidase in corpora lutea of rat ovary by lutropin. Biochemical Journal 166 205-208.

Agarwal SK, Vogel K, Weitsman SR \& Magoffin DA 1999 Leptin antagonizes the insulin-like growth factor-I augmentation of steroidogenesis in granulosa and theca cells of the human ovary. Journal of Clinical Endocrinology and Metabolism 84 1072-1076. (doi:10.1210/jc.84.3. 1072)

Agarwal A, Gupta S \& Sharma RK 2005 Role of oxidative stress in female reproduction. Reproductive Biology and Endocrinology 328. (doi:10.1186/1477-7827-3-28)

Agarwal A, Aponte-Mellado A, Premkumar BJ, Shaman A \& Gupta S 2012 The effects of oxidative stress on female reproduction: a review. Reproductive Biology and Endocrinology 10 49. (doi:10.1186/14777827-10-49)

Ahima RS, Dushay J, Flier SN, Prabakaran D \& Flier JS 1997 Leptin accelerates the onset of puberty in normal female mice. Journal of Clinical Investigation 99 391-395. (doi:10.1172/JCI119172) 
Almog B, Gold R, Tajima K, Dantes A, Salim K, Rubinstein M, Barkan D, Homburg R, Lessing JB, Nevo $\mathbf{N}$ et al. 2001 Leptin attenuates follicular apoptosis and accelerates the onset of puberty in immature rats. Molecular and Cellular Endocrinology 183 179-191. (doi:10.1016/ S0303-7207(01)00543-3)

Angelucci S, Ciavardelli D, Di Giuseppe F, Eleuterio E, Sulpizio M, Tiboni GM, Giampietro F, Palumbo P \& Di Ilio C 2006 Proteome analysis of human follicular fluid. Biochimica et Biophysica Acta 1764 1775-1785. (doi:10.1016/j.bbapap.2006.09.001)

Archanco M, Muruzábal FJ, Llopiz D, Garayoa M, Gómez-Ambrosi J, Frühbeck G \& Burrell MA 2003 Leptin expression in the rat ovary depends on estrous cycle. Journal of Histochemistry and Cytochemistry 51 1269-1277. (doi:10.1177/002215540305101003)

Balasubramaniyan V, Shukla R, Murugaiyan G, Bhonde RR \& Nalini N 2007 Mouse recombinant leptin protects human hepatoma HepG2 against apoptosis, TNF- $\alpha$ response and oxidative stress induced by the hepatotoxin-ethanol. Biochimica et Biophysica Acta 1770 1136-1144. (doi:10.1016/j.bbagen.2007.04.009)

Barkan D, Hurgin V, Dekel N, Amsterdam A \& Rubinstein M 2005 Leptin induces ovulation in GnRH-deficient mice. FASEB Journal 19 133-135.

Barreiro KA, Di Yorio MP, Artillo-Guida RD, Paz DA \& Faletti AG 2011 Daily treatment with $\alpha$-naphthoflavone enhances follicular growth and ovulation rate in the rat. Toxicology and Applied Pharmacology 252 11-17. (doi:10.1016/j.taap.2011.01.007)

Bilbao MG, Di Yorio MP \& Faletti AG 2013 Different levels of leptin regulate different target enzymes involved in progesterone synthesis. Fertility and Sterility 99 1460-1466. (doi:10.1016/j.fertnstert.2012.12.014)

Brown JE \& Dunmore SJ 2007 Leptin decreases apoptosis and alters BCL-2: Bax ratio in clonal rodent pancreatic $\beta$-cells. Diabetes/Metabolism Research and Reviews 23 497-502. (doi:10.1002/dmrr.726)

Cheng G, Weihua Z, Mäkinen S, Mäkelä S, Saji S, Warner M, Gustafsson JA \& Hovatta $\mathbf{O} 2002 \mathrm{~A}$ role for the androgen receptor in follicular atresia of estrogen receptor $\beta$ knockout mouse ovary. Biology of Reproduction $\mathbf{6 6}$ 77-84. (doi:10.1095/biolreprod66.1.77)

Chetboun M, Abitbol G, Rozenberg K, Rozenfeld H, Deutsch A, Sampson SR \& Rosenzweig T 2012 Maintenance of redox state and pancreatic $\beta$-cell function: role of leptin and adiponectin. Journal of Cellular Biochemistry 113 1966-1976. (doi:10.1002/jcb.24065)

Devine PJ, Perreault SD \& Luderer U 2012 Roles of reactive oxygen species and antioxidants in ovarian toxicity. Biology of Reproduction 8627. (doi:10.1095/biolreprod.111.095224)

Dineva J, Wojtowicz AK, Augustowska K, Vangelov I, Gregoraszczuk EL \& Ivanova MD 2007 Expression of atrial natriuretic peptide, progesterone, apoptosis-related proteins and caspase-3 in in vitro luteinized and leptintreated porcine granulosa cells. Endocrine Regulations 41 11-18.

Di Yorio MP, Bilbao MG, Biagini-Majorel AM \& Faletti AG 2013 Ovarian signaling pathways regulated by leptin during the ovulatory process. Reproduction 146 647-658. (doi:10.1530/REP-13-0257)

Duggal PS, Van Der Hoek KH, Milner CR, Ryan NK, Armstrong DT, Magoffin DA \& Norman RJ 2000 The in vivo and in vitro effects of exogenous leptin on ovulation in the rat. Endocrinology 141 1971-1976. (doi:10.1210/en.141.6.1971)

Duggal PS, Weitsman SR, Magoffin DA \& Norman RJ 2002a Expression of the long (OB-RB) and short (OB-RA) forms of the leptin receptor throughout the oestrous cycle in the mature rat ovary. Reproduction 123 899-905. (doi:10.1530/rep.0.1230899)

Duggal PS, Ryan NK, Van der Hoek KH, Ritter LJ, Armstrong DT, Magoffin DA \& Norman RJ 2002b Effects of leptin administration and feed restriction on thecal leucocytes in the preovulatory rat ovary and the effects of leptin on meiotic maturation, granulosa cell proliferation, steroid hormone and PGE2 release in cultured rat ovarian follicles. Reproduction 123 891-898. (doi:10.1530/rep.0.1230891)

Espey LL \& Richards JS 2002 Temporal and spatial patterns of ovarian gene transcription following an ovulatory dose of gonadotropin in the rat. Biology of Reproduction 67 1662-1670. (doi:10.1095/biolreprod.102. 005173)

Espey LL, Yoshioka S, Russell D, Ujioka T, Vladu B, Skelsey M, Fuji S, Okamura H \& Richards JS 2000 Characterization of ovarian carbonyl reductase gene expression during ovulation in the gonadotropin-primed immature rat. Biology of Reproduction 62 390-397. (doi:10.1095/ biolreprod62.2.390)
Fridovich I 1995 Superoxide radical and superoxide dismutases. Annual Review of Biochemistry 64 97-112. (doi:10.1146/annurev.bi.64.070195.000525)

Fujii J, luchi Y \& Okada F 2005 Fundamental roles of reactive oxygen species and protective mechanisms in the female reproductive system. Reproductive Biology and Endocrinology 3 43. (doi:10.1186/1477-7827-3-43)

Griffith OW 1999 Biologic and pharmacologic regulation of mammalian glutathione synthesis. Free Radical Biology \& Medicine 27 922-935. (doi:10.1016/S0891-5849(99)00176-8)

Hanukoglu I 2006 Antioxidant protective mechanisms against reactive oxygen species (ROS) generated by mitochondrial P450 systems in steroidogenic cells. Drug Metabolism Reviews 38 171-196. (doi:10. 1080/03602530600570040)

Karamouti M, Kollia P, Kallitsaris A, Vamvakopoulos N, Kollios G \& Messinis IE 2008 Growth hormone, insulin-like growth factor I, and leptin interaction in human cultured lutein granulosa cells steroidogenesis. Fertility and Sterility 90 1444-1450. (doi:10.1016/j.fertnstert.2007.08.076)

Karamouti M, Kollia P, Kallitsaris A, Vamvakopoulos N, Kollios G \& Messinis IE 2009 Modulating effect of leptin on basal and follicle stimulating hormone stimulated steroidogenesis in cultured human lutein granulosa cells. Journal of Endocrinological Investigation 32 415-419. (doi:10.1007/BF03346478)

Karlsson C, Lindell K, Svensson E, Bergh C, Lind P, Billig H, Carlsson LM \& Carlsson B 1997 Expression of functional leptin receptors in the human ovary. Journal of Clinical Endocrinology and Metabolism 82 4144-4148. (doi:10.1210/jc.82.12.4144)

Kodaman PH \& Behrman HR 2001 Endocrine-regulated and protein kinase C-dependent generation of superoxide by rat preovulatory follicles. Endocrinology 142 687-693.

Kooy NW, Royall JA \& Ischiropoulos H 1997 Oxidation of $2^{\prime}, 7^{\prime}$ dichlorofluorescin by peroxynitrite. Free Radical Research 27 245-254. (doi:10.3109/10715769709065763)

Laloraya M, Pradeep KG \& Laloraya MM 1988 Changes in the levels of superoxide anion radical and superoxide dismutase during the estrous cycle of Rattus norvegicus and induction of superoxide dismutase in rat ovary by lutropin. Biochemical and Biophysical Research Communications 157 146-153. (doi:10.1016/S0006-291X(88)80025-1)

Lam QL, Wang S, Ko OK, Kincade PW \& Lu L 2010 Leptin signaling maintains B-cell homeostasis via induction of Bcl-2 and cyclin D1. PNAS 107 13812-13817. (doi:10.1073/pnas.1004185107)

Lawrence A, Jones CM, Wardman P \& Burkitt MJ 2003 Evidence for the role of a peroxidase compound I-type intermediate in the oxidation of glutathione, $\mathrm{NADH}$, ascorbate, and dichlorofluorescin by cytochrome $\mathrm{C} / \mathrm{H}_{2} \mathrm{O}_{2}$. Implications for oxidative stress during apoptosis. Journal of Biological Chemistry 278 29410-29419. (doi:10.1074/jbc.M300054200)

Lin Q, Poon SL, Chen J, Cheng L, HoYuen B \& Leung PC 2009 Leptin interferes with $3^{\prime}, 5^{\prime}$-cyclic adenosine monophosphate (cAMP) signaling to inhibit steroidogenesis in human granulosa cells. Reproductive Biology and Endocrinology 7 115. (doi:10.1186/1477-7827-7-115)

Lu SC 2009 Regulation of glutathione synthesis. Molecular Aspects of Medicine 30 42-59. (doi:10.1016/j.mam.2008.05.005)

Misra HP \& Fridovich I 1972 The role of superoxide anion in the autoxidation of epinephrine and a simple assay for superoxide dismutase. Journal of Biological Chemistry 247 3170-3175.

Ohkawa H, Ohishi N \& Yagi K 1979 Assay for lipid peroxides in animal tissues by thiobarbituric acid reaction. Analytical Biochemistry 95 351-358. (doi:10.1016/0003-2697(79)90738-3)

Rapoport R, Sklan D \& Hanukoglu I 1995 Electron leakage from the adrenal cortex mitochondrial P450scc and P450c11 systems: NADPH and steroid dependence. Archives of Biochemistry and Biophysics 317 412-416. (doi:10.1006/abbi.1995.1182)

Ricci AG, Di Yorio MP \& Faletti AG 2006 Inhibitory effect of leptin on the rat ovary during the ovulatory process. Reproduction 132 771-780. (doi:10.1530/rep.1.01164)

Richards JS, Russell DL, Ochsner S \& Espey LL 2002 Ovulation: new dimensions and new regulators of the inflammatory-like response. Annual Review of Physiology 64 69-92. (doi:10.1146/annurev.physiol.64.081501.131029)

Rizzo A, Roscino MT, Binetti F \& Sciorsci RL 2012 Roles of reactive oxygen species in female reproduction. Reproduction in Domestic Animals 47 344-352. (doi:10.1111/j.1439-0531.2011.01891.x)

Roman EA, Ricci AG \& Faletti AG 2005 Leptin enhances ovulation and attenuates the effects produced by food restriction. Molecular and Cellular Endocrinology 242 33-41. (doi:10.1016/j.mce.2005.07.007) 
Ruiz-Cortés ZT, Martel-Kennes Y, Gévry NY, Downey BR, Palin MF \& Murphy BD 2003 Biphasic effects of leptin in porcine granulosa cells. Biology of Reproduction 68 789-796. (doi:10.1095/biolreprod.102.010702)

Sailaja JB, Balasubramaniyan V \& Nalini N 2004 Effect of exogenous leptin administration on high fat diet induced oxidative stress. Die Pharmazie 59 475-479.

Sato EF, Kobuchi H, Edashige K, Takahashi M, Yoshioka T, Utsumi K \& Inoue M 1992 Dynamic aspects of ovarian superoxide dismutase isozymes during the ovulatory process in the rat. FEBS Letters 303 121-125. (doi:10.1016/0014-5793(92)80502-8)

Sawada M \& Carlson JC 1996 Intracellular regulation of progesterone secretion by the superoxide radical in the rat corpus luteum. Endocrinology 137 1580-1584.

Shkolnik K, Tadmor A, Ben-Dor S, Nevo N, Galiani D \& Dekel N 2011 Reactive oxygen species are indispensable in ovulation. PNAS $\mathbf{1 0 8}$ 1462-1467. (doi:10.1073/pnas.1017213108)

Sirotkin AV \& Grossmann R 2007 Leptin directly controls proliferation, apoptosis and secretory activity of cultured chicken ovarian cells. Comparative Biochemistry and Physiology. Part A, Molecular \& Integrative Physiology 148 422-429. (doi:10.1016/j.cbpa.2007.06.001)

Slot KA, Voorendt M, de Boer-Brouwer M, van Vugt HH \& Teerds KJ 2006 Estrous cycle dependent changes in expression and distribution of Fas, Fas ligand, $\mathrm{Bcl}-2, \mathrm{Bax}$, and pro- and active caspase-3 in the rat ovary. Journal of Endocrinology 188 179-192. (doi:10.1677/joe.1.06165)

Suzuki T, Sugino N, Fukaya T, Sugiyama S, Uda T, Takaya R, Yajima A \& Sasano H 1999 Superoxide dismutase in normal cycling human ovaries: immunohistochemical localization and characterization. Fertility and Sterility 72 720-726. (doi:10.1016/S0015-0282(99)00332-5)

Tietze F 1969 Enzymic method for quantitative determination of nanogram amounts of total and oxidized glutathione: applications to mammalian blood and other tissues. Analytical Biochemistry 27 502-522. (doi:10. 1016/0003-2697(69)90064-5)

Tsai-Turton M \& Luderer U 2005 Gonadotropin regulation of glutamate cysteine ligase catalytic and modifier subunit expression in rat ovary is subunit and follicle stage specific. American Journal of Physiology. Endocrinology and Metabolism 289 E391-E402. (doi:10.1152/ajpendo. 00531.2004)
Tsai-Turton M \& Luderer U 2006 Opposing effects of glutathione depletion and follicle-stimulating hormone on reactive oxygen species and apoptosis in cultured preovulatory rat follicles. Endocrinology 147 1224-1236. (doi:10.1210/en.2005-1281)

Valko M, Leibfritz D, Moncol J, Cronin MT, Mazur M \& Telser J 2007 Free radicals and antioxidants in normal physiological functions and human disease. International Journal of Biochemistry \& Cell Biology 39 44-84. (doi:10.1016/j.biocel.2006.07.001)

Xu FP, Chen MS, Wang YZ, Yi Q, Lin SB, Chen AF \& Luo JD 2004 Leptin induces hypertrophy via endothelin-1-reactive oxygen species pathway in cultured neonatal rat cardiomyocytes. Circulation 110 1269-1275. (doi:10.1161/01.CIR.0000140766.52771.6D)

Yamagishi SI, Edelstein D, Du XL, Kaneda Y, Guzmán M \& Brownlee M 2001 Leptin induces mitochondrial superoxide production and monocyte chemoattractant protein-1 expression in aortic endothelial cells by increasing fatty acid oxidation via protein kinase A. Journal of Biological Chemistry 276 25096-25100. (doi:10.1074/jbc. M007383200)

Zachow RJ, Weitsman SR \& Magoffin DA 1999 Leptin impairs the synergistic stimulation by transforming growth factor- $\beta$ of folliclestimulating hormone-dependent aromatase activity and messenger ribonucleic acid expression in rat ovarian granulosa cells. Biology of Reproduction 61 1104-1109. (doi:10.1095/biolreprod61.4.1104)

Zamorano PL, Mahesh VB, De Sevilla LM, Chorich LP, Bhat GK \& Brann DW 1997 Expression and localization of the leptin receptor in endocrine and neuroendocrine tissues of the rat. Neuroendocrinology 65 223-228. (doi:10.1159/000127276)

Zhang Y, Proenca R, Maffei M, Barone M, Leopold L \& Friedman JM 1994 Positional cloning of the mouse obese gene and its human homologue. Nature 372 425-432. (doi:10.1038/372425a0)

Received 8 October 2014

First decision 29 October 2014

Revised manuscript received 9 January 2015

Accepted 19 January 2015 